\title{
HEAVY METALS IN WATERS, PENETRATING THE FOOD, ECOSYSTEMS AND THE ECONOMY OF KOSOVO
}

\author{
Adem Dreshaj $^{1}$, Bedri Millaku², Afrim Selimaj ${ }^{3}$, Fidan Feka ${ }^{4}$, Muhamet Kelmendi $^{5}$
}

\begin{abstract}
The waters of the oceans and seas play an important role in the hydrological cycle of the Earth. With Kosovo's economic development, an increasing population has developed many branches of industry that have polluted the rivers with heavy metals, such as the Trepça' mine, and the treatment of agriculture products with pesticides and herbicides. The eutrophication of lakes transitions the metals from agricultural products causing ecological imbalance. Uncontrolled exploitation of natural resources, irresponsible treatment (industrial waste and sewage), has caused contamination above the permitted ecosystem thresholds for toxic elements, such as: $\mathrm{Hg}, \mathrm{Pb}, \mathrm{Cd}, \mathrm{Cu}, \mathrm{Zn}, \mathrm{Ni}$, and $\mathrm{Mn}$. Heavy metals in natural waters that are unpolluted are in low concentration (approximately $1 \mu \mathrm{g} / \mathrm{l}$ ); some are essential for enzymatic reactions in living organisms. Increased concentrations as a result of industrial activities often exceed the allowable limit, causing serious changes to ecosystems, including tourist areas, and to living organisms in aquatic ecosystems. Ecological preservation of ecosystems from heavy metals is vital for the environment, food security, and protecting ecological habitats, and this represent an economic cost for the Republic of Kosovo.
\end{abstract}

UDC Classification: 614, DOI: http://dx.doi.org/10.12955/cbup.v4.743

Keywords: metals, food, ecosystems, economy.

\section{Introduction}

Kosovo aquatic habitats are important for the natural diversity of the nation's flora and fauna. Surface water constitutes an economic asset for our country.

Our objective was to analyze the level of water pollution from heavy metal contamination of these rivers, and the economic cost of the anthropogenic factor. Pollution has serious consequences for living organisms, including the flora and people living in the region (Korzun, 1991). Assessment of heavy metals in food products and the value of the economic cost. Some site-sampling points are monitored. (Dreshaj, 2013). And they have captured a number of heavy elements that have a quantifiable value higher than allowed international standards, as well as rivers in food products.

Understanding the Water Quality of Kosovo RiversOur project aims to provide a better understanding of the quality of river water as part of the natural resources of Kosovo. The emergence of the need for continuous monitoring in partnership with other institutions aims towards preserving aquatic diversity, for present and our future. Heavy metals, such as, $\mathrm{Cu}, \mathrm{Zn}$, and $\mathrm{Cd}$, take part in geochemical processes. Their behavior is governed by adsorption and processes involving complexities of mostly organic and inorganic substances (Lajçi \& Kalaj, 1998).

Table 1 presents the data for the River Drin White and Iber River including the water flow rate $(\mathrm{m} 3 / \mathrm{s})$ at the river surface, volume of water (million $\mathrm{m} 3$ ), the direction of flow, and the water quality standards I to V for certain physical-chemical parameters, to characterize these surface waters.

Metals in rivers occur in ionic forms, as organic or inorganic complexes in solution, tied to colloidal fractions or other suspended materials, but also with living organisms, such as phytoplankton and bacteria. The water quality is important both for the behavior and toxicity of heavy metals.

Table 2 shows heavy metal concentrations for $\mathrm{Cr}, \mathrm{Co}, \mathrm{Ni}, \mathrm{Cu}, \mathrm{Zn}, \mathrm{As}, \mathrm{Mo}, \mathrm{Cd}, \mathrm{Sn}, \mathrm{Hg}, \mathrm{Pb}$, and $\mathrm{S}$ for samples tested according to international standards for permissible parameters for waters.

Table 3 shows the metal concentrations of $\mathrm{Mg}, \mathrm{Al}, \mathrm{Si}, \mathrm{Mn}, \mathrm{Fe}, \mathrm{Co}, \mathrm{Ni}, \mathrm{Cu}, \mathrm{Zn}, \mathrm{As}, \mathrm{Cd}, \mathrm{Au}, \mathrm{Pb}$, and $\mathrm{U}$, from the results of tests by the laboratory in Ontario, Canada. The amount of heavy metals at 10 sampling points of the White Drin river are shown with some sampling points displaying concentrations of metals that exceed expected values for heavy metals in waters.

\footnotetext{
${ }^{1}$ Adem Dreshaj, University of "Haxhi Zeka”, Peja, Kosovo, adem.dreshaj@unhz.eu

${ }^{2}$ Bedri Millaku , University of "Haxhi Zeka", Peja, Kosovo

${ }^{3}$ Afrim Selimaj, University of "Haxhi Zeka", Peja, Kosovo

${ }^{4}$ Fidan Feka, University of "Hasan Pristina ", Pristina , Kosovo

${ }^{5}$ Muhamet Kelmendi, University of "Haxhi Zeka", Peja, Kosovo
} 
Table 1: Watersheds: White Drin and Iber, surface, flow quantity, category water quality assessment

\begin{tabular}{|c|c|c|c|c|c|c|}
\hline No & $\begin{array}{l}\text { Denomina } \\
\text { tion Basin }\end{array}$ & $\begin{array}{l}\text { Length } \\
\mathrm{km}^{2}\end{array}$ & $\begin{array}{l}\text { Flow rate } \\
\mathrm{Q}\left[\mathrm{m}^{3} / \mathrm{s}\right] \\
\end{array}$ & Surface $\mathbf{k m}^{2}$ & $\begin{array}{l}\text { annual leaks } \\
{\left[\text { [million } \mathbf{m}^{3}\right]}\end{array}$ & $\begin{array}{l}\text { Flow } \\
\text { Direction } \\
\end{array}$ \\
\hline 1 & White Drin & 122 & 61.0 & 4.622 & 2.200 & Adriatic Sea \\
\hline 2 & Iber & 42 & 32.6 & 1.155 & 77 & Black sea \\
\hline Category & $\begin{array}{l}\text { Total } \\
\text { hardnes } \\
\mathbf{S} \\
\mathbf{P}_{\text {total }}\end{array}$ & $\mathrm{NO}_{3}{ }^{-}$ & $\begin{array}{l}\mathrm{O}_{2} \\
\text { dissolved } \\
\text { in water }\end{array}$ & $\begin{array}{l}\text { BOD5 } \\
\text { Biochemical } \\
\text { oxygen after } \\
5 \text { days }\end{array}$ & $\begin{array}{l}\text { Spending } \\
\text { chemical } \\
\text { oxygen } \\
\text { SHKO }\end{array}$ & $\mathrm{NH}_{4}{ }^{+}$ \\
\hline Quality I & $<10$ & $<5$ & $>7$ & $<3$ & $<3$ & $<0.1$ \\
\hline Quality II & $10-20$ & $5-25$ & $7-6$ & $3-5$ & $3-10$ & $0.1-0.5$ \\
\hline Quality III & $25-50$ & $25-50$ & 6-4 & $5-9$ & $10-20$ & $0.5-2$ \\
\hline Quality IV & $50-125$ & $50-80$ & $4-3$ & $9-15$ & $20-30$ & $2-8$ \\
\hline Quality V & $>125$ & $>80$ & $<3$ & $>15$ & $>30$ & $>8$ \\
\hline
\end{tabular}

Table 2: International standards for some heavy metals in White Drin

\begin{tabular}{|l|l|l|l|l|l|l|l|l|l|l|l|l|}
\hline No & $\mathbf{C r}$ & $\mathbf{C o}$ & $\mathbf{N i}$ & $\mathbf{C u}$ & $\mathbf{Z n}$ & $\mathbf{A s}$ & $\mathbf{M o}$ & $\mathbf{C d}$ & $\mathbf{S n}$ & $\mathbf{H g}$ & $\mathbf{P b}$ & $\mathbf{S}$ \\
\hline Norma allowed $\boldsymbol{\mu g} / \mathbf{I}$ & 200 & 200 & 200 & 800 & 800 & 100 & 100 & 10 & 150 & 500 & 2 & 200 \\
\hline
\end{tabular}

Source: Author

Table 3: Quantity certain heavy metals in White Drin

\begin{tabular}{|c|c|c|c|c|c|c|c|c|c|c|}
\hline \multicolumn{2}{|c|}{ Element ppm } & \multicolumn{9}{|c|}{ Sampling location } \\
\hline $\mathbf{N r}$ & $D_{1}$ & $\mathbf{D}_{2}$ & $\mathbf{D}_{3}$ & $\mathbf{D}_{4}$ & $\mathbf{D}_{5}$ & $\mathbf{D}_{6}$ & $\mathbf{D}_{7}$ & $\mathbf{D}_{8}$ & D9 & $D_{10}$ \\
\hline Mg & 1680 & 1681 & 1969 & 3771 & 3837 & 3978 & 4133 & 4894 & 5661 & 6639 \\
\hline Al & 14 & 16 & 68 & 40 & 47 & 57 & 41 & 39 & 39 & 48 \\
\hline$\overline{\mathbf{S i}}$ & 9019 & 1207 & 1355 & 1897 & 1879 & 1805 & 2110 & 2217 & 2779 & 2877 \\
\hline Mn & 1.9 & 2.4 & 8 & 12.9 & 12.0 & 18.0 & 12.3 & 13.6 & 13.9 & 34.0 \\
\hline $\mathbf{F e}$ & 59 & 27 & 37 & 42 & 39 & 56 & 43 & 70 & 20 & 55 \\
\hline Co & 0.032 & 0.034 & 0.077 & 0.1 & 0.099 & 0.18 & 0.15 & 0.109 & 0.110 & 0.211 \\
\hline $\mathbf{N i}$ & 1,1 & 1,2 & 0.7 & 1.5 & 0.9 & 1,8 & 1.7 & 1.2 & 1.9 & 2.8 \\
\hline $\mathbf{C u}$ & 22.5 & 3.0 & 9.9 & 4.0 & 6.1 & 3,3 & 9.0 & 11.0 & 4.9 & 4.9 \\
\hline $\mathbf{Z n}$ & 14.4 & 7.7 & 55.8 & 29 & 0224.4 & 4.6 & 21.8 & 12.0 & 50.4 & 26.1 \\
\hline As & 0.08 & 0.10 & 0.28 & 0.380 & 0.30 & 0.39 & 0.34 & 0.300 & 0.434 & 0.656 \\
\hline Cd & 2.43 & 1.99 & 2.7 & 0.27 & 0.18 & 0.2 & 2.3 & 0.96 & 1.35 & 0.78 \\
\hline Au & 0.002 & $<0.02$ & 0.02 & 0.03 & 0.002 & 0002 & 0.03 & $<0.02$ & 0.004 & 0.005 \\
\hline $\mathbf{P b}$ & 28.10 & 35.14 & 14.65 & 5.37 & 2.93 & 4.18 & 24.00 & 9.534 & 9.34 & 5.86 \\
\hline $\mathbf{U}$ & 0.041 & 0.054 & 0.088 & 0.6 & 0.197 & 0.180 & 0.169 & 0.171 & 0.212 & 0.251 \\
\hline
\end{tabular}

\section{Anthropogenic Activity on the Quality of Surface Waters}

Chemical and biological characteristics of water can undergo significant changes as a result of anthropogenic activities. Human actions affect the hydrosphere and lithosphere, for example, the return of forests, pastures in agricultural land, and agricultural products may be contaminated with heavy metals, during the development phase, the use of pesticides and herbicides during the agricultural irrigation ditches. This phenomenon is associated with reducing the amount of water that evaporates from plants, and leads to changes in the microclimate. This will occur as a result of soil erosion, accumulation of sludge in aquatic environments, enriching water with nutrients, and pollutants (Lajçi \& Kalaj, 1998). Accumulation of heavy metals, pathogenic bacteria, such as Escherichia coli contaminate environments and the ecosystems. Plants acquire heavy metals from the 
soil, water, and air. Plant ability to assimilate and accumulate heavy metals depends on the different plant types and is subject to various geochemical conditions.

Chemical and biological processes transform metals and compounds from one form to another form. Various chemical compounds accumulate metals in their tissues, and this is related to bioaccumulation and toxicity. Bioaccumulation of metals and metabolic process is dependent on biological cell transportation, active or passive.

Plant respond to certain elements, depending on the genotype of the plant, the type and total metal concentration, nature of the soil (e.g., mineralogy, $\mathrm{pH}$, redox potential metal, its solubility, and the total content of the of organic matter) and the duration of the presence of water (Qullaj, 2010). Metals in plants pass through active transportation into the endoderm root tissue cells and are then distributed to other parts of the plant. Pathway distribution and transport of metals in plants is from soil> root> stem> leaf, allowing for the existence and possibility for the movement of metals throughout the whole body of the plant. The amount of metal assimilation by plants in general is determined by comparing the total amount of metal present in plants, soil, and plant all or part of its total (Daci, 1978). Studies show that hyperaccumulator plants are plants that must meet three requirements:

1. In their airside, the concentration of metal varies from 100-500 times higher than other plant species in unpolluted environments;

2. The ratio of heavy metal concentration in the area around the root to that within the root must be always higher than one. This indicates higher efficiency in transporting metals from the plant roots in the soil;

3. The ratio of heavy metal concentration in the area around the root to that in the ground must be higher than one. Thus, the metal concentration in plants is higher than in the surrounding earth, and defines the level of assimilation of the metal by the plant. The plant roots directly transfer nutrients and metals from the soil solution (Qullaj, 2010).

Figure 1 shows the process of accumulation of heavy metals in plants, environmental pollution, increase concentration, starting from receipt of the roots during the process of metal ionization, initial leaf to stalk, and carrying out the process of photosynthesis.

Figure: 1 The process of accumulation of heavy metals in plants

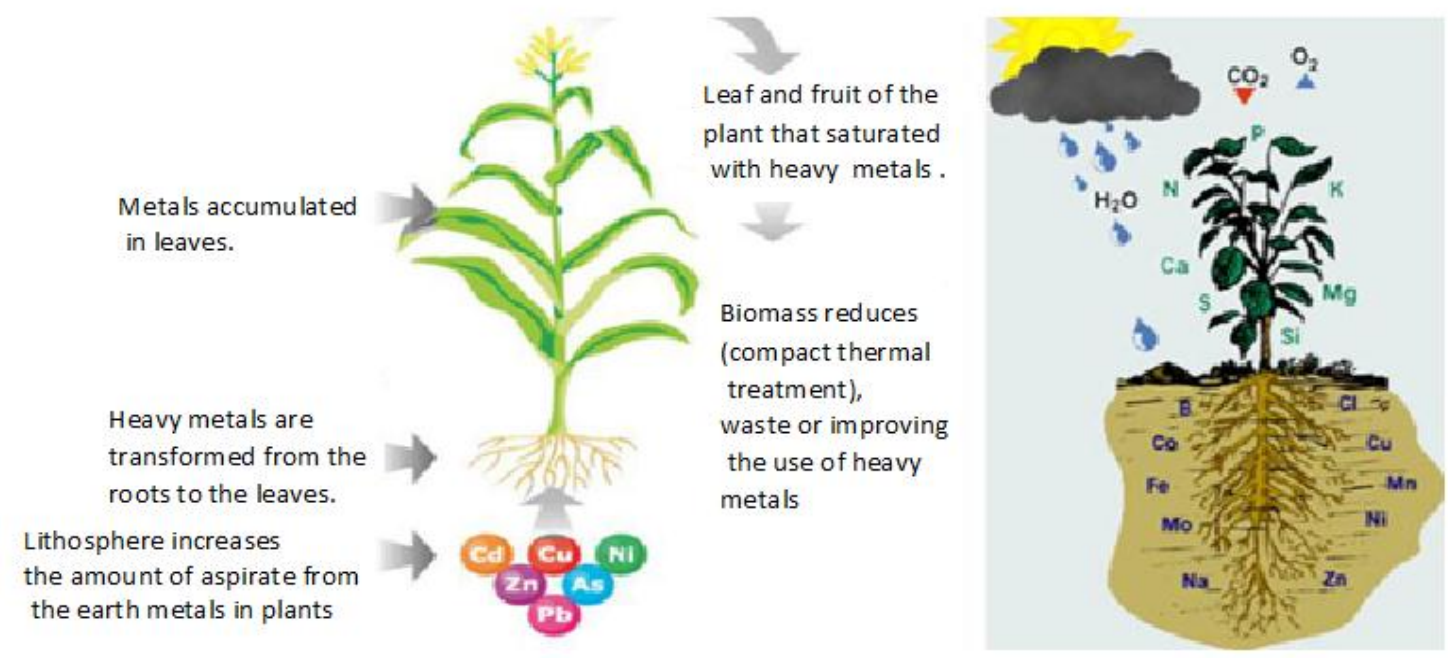

Source: Author

Sources of pollution of natural or anthropogenic origin can be divided into two groups:

- Point source; and

- Non-point-source. 
These are the most significant point sources: liquid discharges of urban waste (sewage), discharges of industrial waste, liquid waste discharges of livestock farms, and rinsing water from landfills and solid waste.

Those that are common non-point sources include runoff from agricultural land, contaminated with precipitation of heavy metals, pipe leakage of sewage, and wastewater washing the streets.

\section{Climate Change in the 21st Century}

The mechanisms of climate change are can be easily explained. The product of burning fossil fuels is carbon dioxide $\left(\mathrm{CO}_{2}\right)$. This $\mathrm{CO}_{2}$ is added to the atmosphere and is the driving force in heating the surface of the Earth. The consequences are observed in the melting of glaciers, flowers bloom sooner, and people and animals are moving to live in altitudes of lower temperatures. Even more disturbing is the realization that the burning of fossil fuels has been adding $\mathrm{CO}_{2}$ to the atmosphere for hundreds of years, but only recently haveconcerns of climate change been voiced by human activists (Qullaj, 2010).

According to statistics, in the past 15 years, Kosovo has lost over $7 \%$ of the forests from illegal logging. In 1980, the usual annual flooding occurred twice in that year, and after 2000, five floods occurred annually (Dreshaj, 2013).

Production yields of bees have reduced due to climate change. In 1999, a bee hive product for sheep was produced at a volume of $55 \mathrm{~kg}$, and by 2016 this had dropped to $10 \mathrm{~kg}$. Agricultural products have decreased by $20 \%$ within 15 years because of climate change, floods, soil erosion, and water use for irrigation of agricultural products with heavy metals.

\section{Negative Effects of Pollution of Surface and Groundwater}

Any environmental contamination has potentially negative effects on the environment. In freshwater eutrophication the main effects are from acidic water and runoff (Favaro, Basaglia, \& Casella, 2012). Eutrophication is a phenomenon that originates from water pollution, mainly from sewage discharge from urban or from agricultural activity as a result of drainage of agricultural land (Qullaj, 2010). The phenomenon of 'laundering more acidic', known in the industry and mining in particular, is the effect caused by discharge of drainage water, which is acidic (from mining), directly into the environment without pre-treatment (Shehu, 2006). The Sitnica River could be referred to as a 'dead' river due to waste disposal and toxic metals from the Trepca mine, since the population of fish have not increased in this river.

\section{Physical Methods of Environmental Studies}

This study measured physical parameters of chemical and bacteriological. Assigned stations were marked by geographic position with a global positioning system (GPS), model Extrax GARMIN, 12 Channel. Identification of heavy elements was performed by induction coupled plasma-mass spectroscopy (ICP-OES), a contemporary method with higher precision than volumetric methods, and chromatographic-based approaches. Samples were analyzed in laboratories in Ontario, Canada and Agrovet in Koosvo Polje for determination of heavy metals in water and agricultural products.

\section{Microorganisms in Natural Waters}

Microorganisms are a highly diverse group of organisms; they include bacteria, fungi, and microscopic plants (green algae). Most are a single cell ().

Microorganisms live in all parts of the biosphere, where there is water, soil, hot springs, in the ocean, the atmosphere, and rocks, deep within the Earth's crust. Microorganisms are critical to nutrient recycling in the ecosystem because they act as decomposers. Some microorganisms can fix nitrogen and are a vital part of its cycle (Daci, 1978). Recent studies indicate that airborne microbes may play a role in precipitation in terms of the weather. Microbes are used in biotechnology, in traditional food, and beverage preparation (Favaro, Basaglia, \& Casella, 2012). However, pathogenic microbes are harmful, since they invade and grow within other organisms, causing diseases that kill humans, animals, and plants. The cells of $E$. coli are typically rod-shaped, cylindrical, and about 2.0 to 0.5 micrometers $(\mu \mathrm{m})$ in diameter, with a cell volume 0.6-0.7. Escherichia coli produces mixed acids. When fermented in anaerobic conditions it produces lactate salt ethanol, acetate, and carbon dioxide. This bacterium, E. coli lives together with hydrogen that feeds on organisms. ). Bacterial structures, 
although not as complex as those of eukaryotes, can be defined several bacterial integral structure. These structures are not found in all the bacteria. The use of antibiotics has greatly accelerated life of humans and without their existence, thousands of people today would not exist, as a result of polio flu viruses or other diseases (Qullaj, 2010). However, some microbes have resulted in a large forward with greater development of treatments in these cases that science interprets where the influenza virus has evolved so quickly as vaccines today is unnecessary and without strong to grippe same next year. Without antibiotics are powerful and create bacteria resistant to microorganisms and bacteria such as "staph," which can be converted into a cell in which a life-threatening infection. Showing other animal diseases as "Ebola" by monkeys, "SARS" from Rodent and avian and swine flu.

\section{Bacteriological Parameters}

All sewage and waste, including from hospitals and urban areas of Peja, Istok, Klina, and other cities, have flowed into the White Drin River during the summer when there is reduced rainfall, falling water levels, and increasing temperature. Such environments create favorable conditions for growth of microorganisms in the water, which is used in agriculture for irrigation of crops as in the region of Prizren, Gjakova, which is distinguished by its fruit and vegetable cultivation. In some cases, in these areas, analytical tests show heavy metals results on the certain parameters indicating the food is contaminated (Dreshaj, 2013).

Usually held coliform bacteria, anaerobes. The number of coliform bacteria, anaerobic, living in all rivers apart from the sampling points that deposits are captured as Escherichia coli, Enterococcus spp., and Pseudomonas aeruginosa, living organisms, hydrogen sulphide-endospore formers anaerobic bacileta, and parasites (Daci, 1978).

With population growth and increased needs for other goods and different the growth of this application makes working factories with greater capacity and thus emit large amounts of greenhouse outdoors, as Kosovo's power plants. Releasing large quantities causes serious harm to human, but also for the environment, increase the amount of poisons after falling to the ground. The amount of the waste plant and a good part of their ends in flowing water, so pollution of the waters has disastrous consequences on animals and plants. Factories emit large amounts of carbon dioxide and the environment has not the capacity to absorb that amount because most of forests are cut down to meet short-term needs for some people while regeneration of these claims requires decades. Mass use of all natural resources in a very short time bring more rapid degradation of the environment (Balkevich, 1984).

Republic of Kosovo has an area of $10,098 \mathrm{~km}^{2}$ with a population of 1.8 million inhabitants, with a poorly developed economy, light industry and agriculture sector average.

Kosovo has 22 rivers to fields other than that used for drinking, despite the weak monitoring in Kosovo, the rest has been able to very poor quality (Dreshaj, 2014).

In Kosovo, are recorded over 103 quarries operating without standards where the majority is located near rivers, greed mercilessly thrown their beds. Biggest polluters are the energy sector of Kosovo and mine Trepça in Mitrovica and urban waste throughout the territory of the Republic of Kosovo. If it does not prevent this phenomenon within very short time will become landfill infection diseases such as, in the basin of the river Ibar and Sitnica where pollution is so great that the river has declined, the Epithets River, has become a 'dead' river. The existence for the fish is impossible, without limiting the eutrophication process, the wastewater discharge from cities which are not pre-treated, and by releasing the water during heavy Basin of Ferro-Nickel plant and mine, Trepça in Kosovo.

In big cities like Pristina Kosovo from air samples taken from recorded large amount of dust, PM5 and PM10, (range $250 \mathrm{mg} / \mathrm{dm}^{3}$ ). According to the Ministry of Spatial Planning (Kosovo's power plants, vehicle traffic (estimated at Republic of Kosovo in circulation over 450,000 vehicles, and 90\% of them do not contain catalyst), and also release $\mathrm{CO}_{2}, \mathrm{CO}$, and $\mathrm{CH}_{4}\left(\mathrm{CH}_{4}\right.$ from landfills waste). In 2014, the central government has launched a project to increase the greenery in Pristina, has planted over 10,000 trees, which do little to soften as the temperature of the city, and reduce $\mathrm{CO}_{2}$ emissions (Dreshaj, 2014).

Villages in Drenas have about 110 inhabitants sick from overdose of heavy metals. Food products are also contaminated with heavy elements of water, air and land. According to health ministry statistics 
in 2015,808 people were sick by carcinogenic substances; these people are treated with substances by chemotherapy to destroy cancer cells.

The cost of chemical treatment per person is $€ 1000$, at least six treatments are needed therapeutic $(1000 \times 6=€ 6,000),(€ 6,000 \times 808=€ 4,848,000)$, excluding precious life that over $70 \%$ of people die in total 808 persons.

Table 4 shows the results at the sampling points for the Iber River Basin up to a kilometer from the river basin, the date of sampling, the type of relief and water level for potatoes sent to the laboratory of Agrovet in Kosovo Polje for chemical analysis.

Table 4: Sampling location sown lands potatoes, Iber River Basin

\begin{tabular}{|l|l|l|l|l|l|}
\hline Sample & Location & $\begin{array}{l}\text { Date/Most } \\
\text { ration hour }\end{array}$ & $\begin{array}{l}\text { Type of } \\
\text { relief }\end{array}$ & $\begin{array}{l}\text { Water } \\
\text { level }\end{array}$ & $\begin{array}{l}\text { Possible } \\
\text { contaminants }\end{array}$ \\
\hline $\mathbf{D}_{\mathbf{1}} / \mathbf{a}$ & $\begin{array}{l}\text { Lismir (in front } \\
\text { of a bridge) }\end{array}$ & $\begin{array}{l}08.05 .2016 \\
10^{00}\end{array}$ & Field & Medium & $\begin{array}{l}\text { River water, } \\
\text { traffic, Air. }\end{array}$ \\
\hline $\mathbf{D}_{\mathbf{1}} / \mathbf{b}$ & $\begin{array}{l}\text { Lismir (in front } \\
\text { of a bridge) }\end{array}$ & $\begin{array}{l}08.05 .2016 \\
10^{30}\end{array}$ & Field & Medium & $\begin{array}{l}\text { River water, } \\
\text { traffic, Air. }\end{array}$ \\
\hline $\mathbf{D}_{2} / \mathbf{a}$ & $\begin{array}{l}\text { Lismir (behind } \\
\text { the bridge) }\end{array}$ & $\begin{array}{l}08.05 .2016 \\
12^{00}\end{array}$ & Field & Medium & $\begin{array}{l}\text { River water, } \\
\text { traffic, Air. }\end{array}$ \\
\hline $\mathbf{D}_{2} / \mathbf{b}$ & $\begin{array}{l}\text { Lismir (Behind } \\
\text { the bridge ) }\end{array}$ & $\begin{array}{l}08.05 .2016 \\
1220\end{array}$ & Field & Medium & $\begin{array}{l}\text { River water, } \\
\text { traffic, Air. }\end{array}$ \\
\hline $\mathbf{D}_{3}$ & $\begin{array}{l}\text { Vushtrri } \\
08.05 .2016\end{array}$ & Field & Medium & $\begin{array}{l}\text { River water, } \\
\text { traffic, Air. }\end{array}$ \\
\hline
\end{tabular}

Source: Author

Table 5 shows the names for sample locations for potatoes and onions taken from parks, habitats, and rural areas rather than a cultivated potato or onion field.

Table 5: Sample locations with the detail description

\begin{tabular}{|l|l|}
\hline $\mathbf{D}_{1} / \mathbf{a}$ & Potatoes \\
\hline $\mathbf{D}_{\mathbf{1}} / \mathbf{b}$ & Onions \\
\hline $\mathbf{D}_{\mathbf{1}} / \mathbf{b}$ & Potatoes \\
\hline $\mathbf{D}_{2} / \mathbf{b}$ & Onions \\
\hline $\mathbf{D}_{\mathbf{3}}$ & Potatoes \\
\hline Source: Author & \\
\hline
\end{tabular}

Table 6 shows the analytical results for potato samples tested at the laboratory of Agrovet in Kosovo Polje. All elements of the suite of heavy metals: $\mathrm{As}, \mathrm{Zn}, \mathrm{Pb}, \mathrm{Hg}, \mathrm{Cu}, \mathrm{Cd}$, and $\mathrm{Ni}$, were above the permitted international standards. Food products could be contaminated where this river water is used for irrigation of Sitnica agricultural products.

Table 6: The amount of heavy metals in Potatoes

\begin{tabular}{|l|l|l|l|l|l|l|l|l|l|l|}
\hline $\begin{array}{c}\text { Element } \\
\text { ppm }\end{array}$ & \multicolumn{10}{|c|}{ Sampling location } \\
\hline & $\mathbf{D}_{\mathbf{1}}$ & $\%$ & $\mathbf{D}_{\mathbf{1}} / \mathbf{b}$ & $\%$ & $\mathbf{D}_{\mathbf{3}}$ & $\boldsymbol{\%}$ & $\mathbf{D}_{2} / \mathbf{b}$ & $\boldsymbol{\%}$ & $\mathbf{D}_{\mathbf{3}}$ & $\%$ \\
\hline As & 3.1115 & 0.0003 & 2.2258 & 0.0002 & $<0.002$ & -- & $<0.002$ & -- & $<0.002$ & - \\
\hline $\mathbf{Z n}$ & 21.651 & 0.002165 & 70.13355 & 0.00701 & 11.725 & 0.00117 & 32.49166 & 0.003249 & 4.060983 & 0.000406 \\
\hline $\mathbf{P b}$ & 1.4611 & 0.000146 & 3.920875 & 0.000392 & 2.728127 & 0.000273 & 1.52224 & 0.000152 & $<0.001$ & - \\
\hline $\mathbf{H g}$ & $<0.001$ & -- & $<0.001$ & - & $<0.001$ & -- & $<0.001$ & -- & $<0.001$ & - \\
\hline $\mathrm{Cu}$ & 9.986 & 0.001 & 18.116 & 0.002 & 28.474 & 0.003 & 13.769 & 0.001 & 5.392 & 0.001 \\
\hline $\mathbf{C d}$ & $<0.001$ & -- & $<0,001$ & - & $<0.001$ & -- & $<0.001$ & -- & $<0.001$ & - \\
\hline $\mathbf{N i}$ & 2.596714 & 0.00026 & 2.933286 & 0.000293 & 42.270 & 0.004227 & 3.569094 & 0.000357 & 1.952208 & 0.000195 \\
\hline
\end{tabular}




\section{The Amount of Waste Produced and the Economic Cost}

The waste system is a necessity to preserve the environment, but also deals with agro-products, and other contaminants of soil, water, and air. Thus, this affects the cost-effectiveness for the economic development of a country in the use of raw materials. Gathering of urban waste is economically viable and in this research was conducted in four municipalities in the Republic of Kosovo.

\begin{tabular}{|c|c|c|c|c|c|c|}
\hline Year / 2015 & Gjilan & Viti & Kamenicë & Novobërdë & Bones & Total \\
\hline January & $1,351.64$ & 258.52 & 187.94 & 106.68 & & $1,904.79$ \\
\hline February & $1,168.85$ & 227.42 & 194.97 & 98.00 & 1.40 & $1,690.64$ \\
\hline March & $1,327.80$ & 241.74 & 219.18 & 118.86 & 0.38 & $1,907.96$ \\
\hline April & $1,457.67$ & 272.09 & 248.20 & 134.15 & 2.64 & $2,114.75$ \\
\hline May & $1,517.29$ & 296.05 & 261.82 & 140.32 & 8.33 & $2,223.81$ \\
\hline June & $1,535.25$ & 283.61 & 258.62 & 133.23 & 5.22 & $2,215.93$ \\
\hline July & $1,952.73$ & 372.30 & 331.55 & 144.95 & 17.99 & $2,819.52$ \\
\hline August & $1,946.32$ & 384.53 & 144.68 & 342.62 & 27.62 & $2,846.07$ \\
\hline September & $1,742.76$ & 344.24 & 325.81 & 155.65 & 22.77 & $2,591.23$ \\
\hline October & $1,805.81$ & 207.02 & 267.44 & 203.08 & 5.67 & $2,489.02$ \\
\hline November & $1,497.74$ & 299.86 & 264.74 & 132.18 & 0.32 & $2,194.84$ \\
\hline December & $1,444.94$ & 300.38 & 252.50 & 134.16 & 096 & $2,227.62$ \\
\hline Amount /2015 & $18,748.78$ & $3,487.76$ & $2,957.45$ & $1,843.88$ & 93.60 & 27.226 .17 \\
\hline Price to $(€)$ & $112,701.31 €$ & $20,989.46 €$ & $17,740.38 €$ & $11,089.52 €$ & $7,433.89 €$ & $169,954.56 €$ \\
\hline $\begin{array}{l}\text { No. of Clients } \\
\end{array}$ & 11,021 & 2,946 & 2,473 & 1,247 & & \\
\hline Our customer & 1.70 & 1.18 & 1.20 & 1.48 & & \\
\hline
\end{tabular}

Table 7 shows submission of urban waste collection, in four municipalities of Kosovo, that is, the amount collected for 12 months during 2015. The economic cost was calculated in euro and was compared to the damage caused to the environment and the people that suffered from various tumors.

\begin{tabular}{|c|c|c|c|c|c|c|}
\hline Year / 2016 & Gjilan & Viti & Kamenicë & Novobërdë & Bones & Total \\
\hline January & $1,312.49$ & 289.92 & 211.26 & 99.22 & 0.24 & $1,913.13$ \\
\hline February & $1,328.13$ & 294.94 & 208.72 & 117.10 & 0.58 & $1,949.47$ \\
\hline March & $1,447.40$ & 383.22 & 249.28 & 130.02 & 0.64 & $2,210.56$ \\
\hline April & $1,571.81$ & 337.10 & 264.28 & 140.36 & 1.04 & $2,314.59$ \\
\hline Amount /2016 & $5,659.83$ & $1,305.18$ & 933.54 & 486.70 & 2.50 & $8,387.75$ \\
\hline Price to $(€)$ & $32,430.83 €$ & $7,478.68 €$ & $5,349.18 €$ & $2,788.79 €$ & $189.00 €$ & $48,236.48 €$ \\
\hline $\begin{array}{l}\text { Number of } \\
\text { Clients }\end{array}$ & 10,911 & 3,144 & 2,532 & 1,218 & & \\
\hline Our customer & 052 & 042 & 037 & 040 & & \\
\hline
\end{tabular}

Table 8 shows the submission for urban waste collection, in the four municipalities of Kosovo, that is, the amount collected in four months of 2016 with calculation of economic costs in euro, and compared with environmental damage.

\section{Discussion}

From the results obtained, the quality of $\mathrm{Zn}$ in the water of the White Drin is mainly in the class, ITE, and breaker, by $\mathrm{Cd}$, class-breaker will, its third and $\mathrm{IV}$, according to $\mathrm{Pb}$, in the class of its third and $\mathrm{IV}$, by $\mathrm{Cu}$, in II and its third class.

Ten sampling points showed that in the White Drin River, the parameters of heavy metals did not exceed the permitted international norms, in a comparison with standard parameters. Concentrations of elements that are presented in Table 3 show $\mathrm{Cu}$ is classified in position II except for D8-D10, which are classified in position III. Concentrations of $\mathrm{Pb}$ are classified in position IV, except in position D5-D6, which are classified in the III position. 
Bacteriological parameters during the summer indicate the river is contaminated with bacteria, especially E. coli.

The situation is highly degraded in the basins of the rivers, Ibar and Sitnica, based on the results from the laboratory in Ontario, Canada. Parameters of heavy metals in food products, such as potato that were analyzed every $1000 \mathrm{~m}$ for a kilometer from river shore in agricultural land planted with potatoes and irrigated with water from the river. Heavy metals: $\mathrm{As}, \mathrm{Zn}, \mathrm{Pb}, \mathrm{Hg}, \mathrm{Cu}, \mathrm{Cd}$, and $\mathrm{Ni}$, in the potatoes shown in Table 6 were compared with international standards ranging from 150-200 ppm, allowed for international settings.

Based on the analysis of economic costs for treating people with chemical therapy to destroy cancer cells the state pays $(€ 4,848,000)$.

However, waste management in the four municipalities has economic value $(€ 48,236.48+$ $€ 169,954.56=€ 218,191.04)$.

State governments account economic waste management; environmental conservation of ecosystems; preservation of human life, flora, and fauna; and conservation of water, air, and soil.

\section{Recommendation}

Recent reports of human development pose environmental degradation that threatens global progress for the poor. According to the report, inaction to climate change and environmental degradation threatens ecosystems health and income growth in developing countries, in these ways:

In terms of national and international diplomacy; need a positive outcome in a broad base of national and international cooperation, to an active treatment, prevention of pollution sources and water protection;

Harmonization of national legislation with international protection and promotion; aquatic environment in their respective fields, as well as its correct implementation;

Intensify cooperation locally, between neighboring countries, and at a regional and international level, Take appropriate and concrete measures to protect and improve the environment and life atn the state and local level (through appropriate inspection oversight institutions);

Construct facilities for water purification (as providers); landfill for waste collection;

Propose non-polluting production methods; gas and water plants with emissions processed for low concentrations of air, soil, and water pollutants.

\section{Conclusions}

Scientific research performed in Republic of Kosovo is often based onwith unreliable data. The number of employee sick days ascertained from the Ministry of Health for the year 2015-16, the suspected carcinogens from heavy metal contamination of water, air, and land, add economic cost. It is estimated that the economic cost for persons falling ill from deadly diseases is regarded by the Republic of Kosovo government not by counting people's lives that within two to three years, most of them die. It is estimated the economic cost of waste collection has been calculated without estimating the economic cost in monetary terms for the environmental damage. Raising awareness for nature protection in citizens and government and non - governmental organizations involves education, media, brochures, and campaigning for such purposes by citizens of different ages, especially the younger generations.

\section{References}

Balkevich, V. L. (1984). Advanced Ceramics (Russian). M.: Stroyizdat.

Daci, N. (1978). Organic Chemistry, University Natural Sciences Pristina: 04nr.413-235/80.

Dreshaj, A. (2013). Doctorate: Study chemical - environmental watershed White Drin and Ibar in Kosovo. University Tirana www.fshn.edu.al.

Dreshaj, A. (2014). Product Quality Management and Environmental Impacts in Business, Pristina. Olymp; ISBN, 9789951-635-32-5.

Favaro, L., Basaglia, M., \& Casella, S. (2012). Processing wheat bran into ethanol using mild treatments and highly fermentative yeasts. Biomass and Bioenergy, 46, 605-617.

Korzun, I. N. (1991). Laboratornyye raboty po mekhanike i molekulyarnoy fizike [Laboratory work on mechanics and molecular physics]. Almaty, Kazakhstan: Kazakh University.

Lajçi, A., \& Kalaj, V. (1998).Chemistry, University of Pristina, Faculty of Natural Sciences. Nr .177/28 (1997).

Qullaj, A. (2010).Environmental Chemistry, University of Tirana, Faculty of Natural Sciences, ISBN: 978-99927-0-562-9.

Shehu, E. (2006).Basics of Chemical and Environmental Technology, Tirana University of Tirana, Faculty of Natural

Sciences: ISBN 99927-931-3-9. 